Tamara Rajić ${ }^{1}$

Ivan Nikolić

Isidora Milošević ${ }^{3}$
JEL: M31, I23, C31

DOI: 10.5937/industrija47-22044

UDC: 005.6:378.1(497.11)

005.346

Original Scientific Paper

\title{
An Integrative Model of Relationship Quality in Higher Education Setting: Evidence from Serbia $^{4}$
}

\author{
Article history: \\ Received: 7 April 2019 \\ Sent for revision: 15 April 2019 \\ Received in revised form: 27 May 2019 \\ Accepted: 28 May 2019 \\ Available online: 4 July 2019
}

\begin{abstract}
The objective of this study is to examine the formation of relationship quality and its consequences in higher education setting. The study draws on extant literature in service businesses and proposes teachers' customer orientation as an antecedent to relationship quality, encompassing trust and satisfaction, and relationship continuity and word-of-mouth (WOM) communication as consequences of students' perceptions of relationship quality. Structural equation modelling was applied to analyse survey data collected on a convenience sample of 236 students attending a small public faculty in Serbia. The results show that trust and satisfaction mediate the impact of teachers' customer orientation on relationship continuity and WOM. Both trust and satisfaction emerged as direct positive determinants of WOM, whereas the impact of trust on relationship continuity is mediated via student satisfaction. Implications and limitations of the study are discussed and future research directions are provided.
\end{abstract}

Keywords: customer orientation, relationship quality, satisfaction, trust, relationship continuity, word-of-mouth, higher education.

\footnotetext{
${ }^{1}$ Economics Institute a.d. Belgrade, tamara.rajic@ecinst.org.rs

${ }^{2}$ Economics Institute a.d. Belgrade

${ }^{3}$ University of Belgrade, Technical faculty in Bor

4 The paper is a result of a project no. 179001 financed by the Ministry of Education, Science and Technological Development of the Republic of Serbia
} 
Rajić T. et al.: An Integrative Model of Relationship Quality in Higher Education...

\section{Integrativni model kvaliteta odnosa sa korisnicima u oblasti visokog obrazovanja: istrazivanje u Srbiji}

Apstrakt: Cilj ovog rada je ispitati formiranje kvaliteta odnosa sa korisnicima $i$ njegove posledice u kontekstu visokog obrazovanja. Rad se oslanja na postojeću literaturu u uslužnim delatnostima i predlaže orijentaciju prema korisnicima od strane nastavnika kao determinantu kvaliteta odnosa sa korisnicima, koja obuhvata poverenje i satisfakciju, kao i kontinuitet odnosa $i$ usmenu propagandu kao konsekvence percepcije studenata u vezi sa kvalitetom odnosa. Modelovanje uz pomoć strukturnih jednačina primenjeno je za analizu podataka prikupljenih na prigodnom uzorku od 236 studenata malog državnog fakulteta u Srbiji. Rezultati pokazuju da poverenje $i$ satisfakcija studenata posreduju u uticaju orijentacije nastavnika prema korisnicima na kontinuitet odnosa $i$ širenje usmene propagande. I poverenje $i$ satisfakcija studenata pojavili su se kao direktne pozitivne determinante širenja usmene propagande, dok je uticaj poverenja na kontinuitet odnosa posredovan satisfakcijom studenata. $U$ radu su razmotrene implikacije $i$ ograničenja studije i date su smernice za buduća istraživanja.

Ključne reči: orijentacija prema korisnicima, kvalitet odnosa, satisfakcija, poverenje, kontinuitet odnosa, usmena propaganda, visoko obrazovanje

\section{Introduction}

Over previous three decades relationship marketing has attracted much attention among researchers and practitioners. It has been regarded as a new marketing paradigm, which brought the change of focus from establishing short-term discrete transactions to building and maintaining mutually beneficial long-term relationships with valued customers. Studies on relationship quality, factors which influence the establishment of high quality relationships and benefits of relationship quality have been conducted across B2B and B2C markets. Intensification of competitive pressures in production and service businesses spurred academics' and practitioners' interest on studying determinants and effects of relationship quality. It can be said that higher education setting worldwide has been intensively exposed to competitive pressures over previous two decades. The same applies to higher education context in Serbia. The number of faculties increased from 76 in the academic year $1999 / 2000$ to 130 by the end of $2009 / 2010$, or by $71 \%$. The average annual growth rate of the number of faculties in that period amounted to $6 \%$, whereas the average rate of growth of faculties per million inhabitants was more intense and amounted to $6.8 \%$. After the academic year 2009/2010, the number of faculties has stagnated, but the number of enrolled students 
Rajić T. et al.: An Integrative Model of Relationship Quality in Higher Education...

has been increasing, despite the trend of depopulation (Statistical office of the Republic of Serbia, 1999-2018).

Long-running dispute of the validity of adopting marketing orientation and applying business concepts in managing higher education institutions, which has been conducted in academic circles over previous two decades (See e.g. Guilbault, 2018), has brought about a number of voices supporting 'student as a customer' and 'higher education institution as a marketer' stances, emphasizing at the same time the absence of any trade-off between retaining academic integrity and providing high quality study experience to students (Rojas-Méndez et al., 2009; Guilbault, 2016; Meštrović, 2017) According to Guilbault (2016) the notion that students must not be treated as customers stems from a false interpretation that students should be given whatever they want (i.e. undeserved high grades), if they are treated as customers. The author further claims that students should be perceived as co-creators of educational experience, and their satisfaction with the experience should be of high relevance to higher education institutions, if institutions want to retain existing students, instead of focusing on several times more expensive practice of attracting new students. Moreover, it has been further explained that to reap beneficial effects higher education institutions should adopt customer-oriented approach on things like respect towards students, courtesy, willingness to help students rather than making compromises on the substance of teaching or the evaluation of students' performance.

In higher education environment, characterized by unprecedented internationalization and rising competitive pressures, how to establish good relationship with students and promote students' loyalty, i.e. relationship continuity and WOM communication, become critical for administrators of higher education institutions. In spite of few empirical studies on relationship quality in higher education context (e.g. Rojas-Méndez et al., 2009), limited research efforts have been made to examine an integrative model of relationship quality, its components and consequences in a higher education setting. Therefore, this study aims to bridge this gap and enrich relationship marketing literature by the examination of the determinants and effects of relationship quality in higher education setting from the perspective of students as customers of higher education institutions' services.

The paper is structured as follows. First, building upon review of previous research in service industries, we examine the construct of relationship quality and propose teachers' customer orientation as a determinant of relationship quality and relationship continuity and students' willingness to promote higher education institution as consequences of good relationships with students. Methodology of the study is presented next, which is followed by the discussion of research findings and implications of the study. We present a 
Rajić T. et al.: An Integrative Model of Relationship Quality in Higher Education...

brief overview of the study's limitations and provide directions for future research.

\section{Literature review and hypothesis development}

\subsection{Relationship quality}

In spite of a large body of literature on relationship quality across service settings, such as financial services (Bejou et al., 1996; Rajaobelina \& Bergeron, 2009), transportation (Cheng et al., 2008), hospitality (Kim \& Cha, 2002; Taylor et al., 2018), health care (Hsieh \& Hiang, 2004; Huang et al., 2014), relatively few studies have examined the construct in higher education setting. A consensus as to the common definition of the construct has not been reached yet. Previous studies have proposed various definitions of relationship quality. Bejou et al. (1996) were among the first authors who addressed the construct of relationship quality in B2C context. The authors explained relationship quality as a customer's reliance on an exchange partner's integrity and confidence in an exchange partner's future performance, which are based on consistently satisfying previous performance of the exchange partner. According to Rajaobelina and Bergeron (2009) relationship quality is an overall assessment of a strength of a relationship between a customer and a company. In a similar vein, Kim et al. (2006) explained relationship quality as a customer's assessment of how well the relationship fulfils customer's needs, goals and desires.

Review of past studies reveals that relationship quality can be regarded as a compound construct comprising customer's trust in a service provider and satisfaction with the provider (Hsieh \& Hiang, 2004; Cheng et al., 2008; Huang et al., 2014; Taylor et al., 2018; Wu et al., 2019). High quality of a relationship implies that a customer is satisfied with previous performance of a provider and can rely on the provider's future performance.

Trust is regarded as the main precondition to successful relationships (Harris \& Goode, 2004; Cheng et al., 2008). According to Morgan and Hunt (1994) trust implies confidence in an exchange partner's reliability and integrity. In the context of higher education students' trust is developed through their interactions with university employees and it is regarded as an important determinant of long-term relationships between universities and their graduates. Higher education institutions that manage to instil trust into their students can benefit in several ways (Ghosh et al., 2001). Trusting students are more likely to refer study course to their acquaintances and influence enrolment decisions of others, therewith contributing to lessening of recruitment costs. Alumni who trust their higher education institution may 
Rajić T. et al.: An Integrative Model of Relationship Quality in Higher Education...

contribute financially to research and other activities of the institution. Ghosh et al.'s (2001) study on a sample of college students indicated perceived sincerity of the college, students' perceptions of college employees' expertise, congeniality, openness and integrity as significant determinants of student trust in the college.

Satisfaction has been regarded as a key determinant of customer future behaviour and his or her decision to maintain or terminate relationship with a provider. Satisfaction can be explained as "the degree to which the performances meet customers' expectations" (Hsieh \& Hiang, 2004; p.45). Using critical incident technique on a sample of students attending business studies in the UK, Douglas et al. (2015) identified attentiveness of university employees to students' needs, the ability to understand students and readiness to provide help and support as the main factors which contribute to student satisfaction.

Despite the importance of both student trust in academic institution and satisfaction on the development of long-term relationships with students, little attention has been focused on the relationship between these constructs in higher education setting, However, numerous studies in service businesses have provided empirical support for the impact of trust on customer satisfaction (Chiou, 2004; Harris \& Goode, 2004; Izogo, 2016; Sharma \& Sharma, 2019; Wu et al., 2019)

Based on these previous findings, the following hypothesis is proposed:

H1: Students' trust in a higher education institution positively influences satisfaction.

\subsection{Customer orientation}

Customer orientation can be defined as "the practice of the marketing concept at the level of the individual salesperson and customer" (Saxe \& Weitz, 1982; p.343). It is reflected in a service personnel's empathy, understanding, concern for customers and orientation towards satisfying customers' needs in a manner superior to its competitors (Cheng et al., 2008). According to Narver and Slater (1990), who were among the first authors who thoroughly addressed the construct of customer orientation, it can be explained as the orientation of companies towards the creation of superior value for customers, which is based not only on the current understanding of customers' needs and wants, but implies also the anticipation of customers' latent needs. The aforementioned authors proposed customer orientation as a component of a higher-order construct market orientation, which in addition to customer orientation comprises orientation towards competitors and interfunctional coordination. Kirca et al. (2005) argue that by the adoption of market orientation companies are well positioned to anticipate customers' needs and 
Rajić T. et al.: An Integrative Model of Relationship Quality in Higher Education...

provide offerings which would satisfy those needs and therefore market orientation is imperative for the survival of service businesses. Recent research in food-processing industry supported positive impact of marketing orientation on return of sales, return on investments, return on assets, employees' commitment, whereas the strongest positive effect has been recorded on the relationship between marketing orientation and customer satisfaction (Šályová et al., 2015). The importance of adopting marketoriented behaviour and nurturing market oriented business culture, as necessary prerequisites to the achievement of superior business performance, are particularly highlighted in terms of rising competitive pressures (Šályová et al., 2017). According to Casidy (2014), in order to retain existing students for higher levels of study and attract new students, "higher education institutions must focus on developing a strong market orientation" (p.155). The author further claimed that market-oriented universities understand students' needs and the benefits of establishing long-term relationships with students. Recent study in a health care context revealed significant impact of hospital's market orientation, consisting of customer orientation, orientation towards competitors and interfunctional coordination, on patients' perceptions of quality of a relationship with the hospital (Huang et al., 2014). Voon (2008) was among the first authors who examined the construct of market orientation in higher education setting. The author proposed six-dimensional service-driven market orientation measurement instrument (SERVMO), comprising customer orientation, competitor orientation, interfunctional coordination, performance, employee and longterm orientation and indicated significant associations between university's market orientation and student satisfaction and loyalty. According to the author, customer orientation is at the heart of market orientation. In service businesses, such as higher education, interactions between employees and customers play an important role in satisfying customer needs and desires. Teachers are the most important frontline personnel of educational institutions, and their positive attitude and behaviour towards students bear the potential to reduce informational asymmetry at the side of students, which is inherent to services rich in credence attributes.

Previous research in a service setting provided support to significant impact of interaction between customers and frontline personnel, i.e. personnel's expertise, attitude and behaviour towards customers, on relationship quality as perceived by customers (Qin et al., 2009). Referring to service businesses, Kim and Cha (2002) assert that relationship quality emanates from customerservice employee interactions and customers' perceptions of employees' communication and behaviour, i.e. their attitude revealing respect for customers, courtesy towards customers, empathy, warmth and willingness to help customers. Cheng et al's (2008) study in an airline setting indicated customer orientation as the most significant determinant of relationship 
Rajić T. et al.: An Integrative Model of Relationship Quality in Higher Education...

quality, comprising trust and satisfaction. Previous research in higher education setting indicates significant impact of institutions' market orientation, as perceived by students, on student satisfaction (Casidy, 2014). According to Guilbault $(2016 ; 2018)$ the adoption of customer orientation by higher education institution will have a positive effect on student satisfaction and retention. On a sample of academic staff from England and Israel, Hemsley-Brown and Oplatka (2010) studied the degree of adoption of market orientation among two higher education institutions and suggested the relevance of market orientation of academic institutions for building and maintaining strong relationships with students.

Therefore, building upon previous research in service businesses, we propose the following hypotheses:

H2. Teachers' customer orientation has a direct and positive effect on student trust in a higher education institution;

H3. Teachers' customer orientation has a direct and positive impact on student satisfaction with a higher education institution.

\subsection{Relationship continuity and word of mouth intentions}

Customer loyalty is defined as a "deeply held commitment to rebuy or repatronize a preferred product or service consistently in the future, despite situational influences and marketing efforts having the potential to cause switching behaviour" (Oliver, 1997, p.392). In higher education setting student loyalty is reflected in willingness to attend further education at the same institution, or probability of attending the same university if starting anew, and willingness to spread positive WOM about the institution (Helgesen \& Nesset, 2007). In increasingly competitive higher education market, where institutions are also faced with financial constraints, alumni loyalty is regarded as a key factor of institutions' success and survival (Schlesinger et al., 2017; Ismanova, 2019). Satisfied alumni may contribute to the promotion of institution's image and new enrolments by recommending their graduate programme to acquaintances. Satisfied alumni or their employers may provide financial support for institution's research projects, facilitate the employment of fresh graduates of their higher education institution and contribute to the establishment and maintenance of cooperation between university and industry (Rojas-Méndez et al., 2009; Annamdevula \& Bellamkonda, 2016; Schlesinger et al., 2017). Previous research in higher education setting indicates significant impact of student satisfaction on their willingness to continue a relationship with the same institution and provide positive referrals about the institution (Dado et al., 2013; Casidy, 2014; Annamdevula \& Bellamkonda, 2016; Meštrović, 2017). Similarly, Schlesinger et al.'s (2017) study on a sample of 1000 alumni of two Spanish public universities indicated 
Rajić T. et al.: An Integrative Model of Relationship Quality in Higher Education...

significant direct impact of both trust and satisfaction on alumni loyalty, whereas the impact of satisfaction on loyalty was much greater (0.658 vs. 0.181).

Based on the findings of previous research, we put forth the following hypotheses:

H4. Student trust has a direct positive effect on relationship continuity;

H5. Student trust has a direct positive effect on their willingness to spread positive word-of-mouth about the faculty;

H6. Student satisfaction has a direct positive impact on relationship continuity;

H7. Student satisfaction has a direct positive impact on their willingness to spread positive word-of-mouth about the faculty.

A conceptual model which integrates hypothesized relationships is presented in Figure 1.

Figure 1. The conceptual model

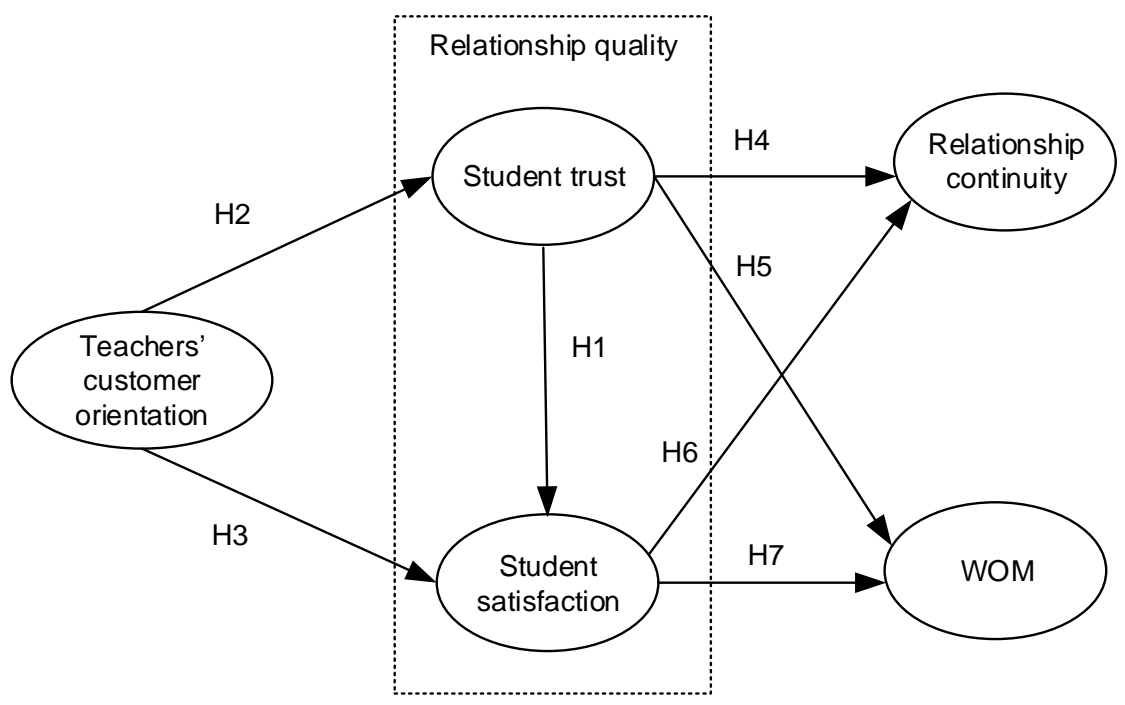

Source: authors' presentation 
Rajić T. et al.: An Integrative Model of Relationship Quality in Higher Education...

\section{Methodology}

The sample was drawn from the population of undergraduate students of one public faculty located in Eastern Serbia. Research has been performed on a convenience sample of students of all four years of bachelor studies, who were present at the faculty during the days of data collection. Teachers were asked for permission to allow data collection at the end of their classes. In total, 280 responses were received, of which 44 questionnaires were excluded from further analyses on the grounds of incomplete data. Effective response rate was $84.3 \%$ (236 out of 280 distributed questionnaires).

Thorough literature review provided the basis for initial version of the questionnaire. Prior to quantitative research, the questionnaire was pilot tested on a sample of 30 students, to assure that items are meaningful to higher education setting and that they can be easily understood. Pilot test resulted in minor refinement of questionnaire items. Students were instructed to respond to questionnaire items taking into account their cumulative experiences with the faculty and its teaching staff. Although previous research in higher education setting examined the impact of market orientation on student satisfaction, group discussions with students indicated that they were not confident in assessing competitor orientation, employee orientation nor interfunctional coordination. Therefore, this study took into account customer orientation as a determinant of relationship quality, as students had enough experience with the institution to assess this dimension of market orientation.

Items included in the questionnaire were adapted from previous research. To measure students' perceptions of teachers' customer orientation we proposed eight items based on previous research developed by Cheng et al (2008) and Hemsley-brown and Oplatka (2010). Trust was assessed with three items proposed by Schelsinger et al. (2017). Three items were used to measure customer satisfaction which were adapted from Casidy (2014) and Schlesinger et al. (2017). Items related to relationship continuity and WOM were adapted from Kim and Cha (2002) and Helgesen and Nesset (2007). Students were asked to indicate their level of (dis)agreement with questionnaire items on a 7-point Likert-type scale, ranging from 1-completely disagree to 7-completely agree.

Hypothesized relationships were examined by the application of structural equation modelling (SEM), using Amos 16. Confirmatory factor analysis was performed first, to assess validity of the constructs included in the proposed model. Satisfactory fit of the measurement model allowed for the application of structural analysis. 
Rajić T. et al.: An Integrative Model of Relationship Quality in Higher Education...

\section{Results}

Confirmatory factor analysis was performed first, to verify constructs' unidimensionality. An acceptable degree of model fit was obtained $(\mathrm{X} 2 / \mathrm{df}=2.49, \mathrm{GFI}=0.893, \mathrm{AGFI}=0.854, \mathrm{CFI}=0.949, \mathrm{NFI}=0.909, \mathrm{NNFI}=0.937$, RMSEA $=0.07$ ), as $X 2 / \mathrm{df}$ ratio was lower than 5 (Harris \& Goode, 2004) and Comparative fit index (CFI), Normed fit index (NFI) and Non-normed fit index (NNFI) were above the recommended minimum level of 0.90 and Root mean square error of approximation (RMSEA) value was lower than 0.08 (Annamdevula \& Bellamkonda, 2016). Both GFI and AGFI appeared to be a bit lower than the recommended threshold, however, very close to 0.90 .

Table 1. Measurement model results

\begin{tabular}{|c|c|c|c|c|}
\hline Constructs and items & $\begin{array}{l}\text { St. factor } \\
\text { loadings* }\end{array}$ & $\begin{array}{c}\text { Cronbach's } \\
\text { alpha }\end{array}$ & CR & AVE \\
\hline Teachers' customer orientation & & 0.897 & 0.897 & 0.523 \\
\hline Teachers are always polite with students & 0.661 & & & \\
\hline Teachers are attentive to students' concerns & 0.730 & & & \\
\hline $\begin{array}{l}\text { When a student has a problem, teachers show } \\
\text { sincere interest in solving it }\end{array}$ & 0.720 & & & \\
\hline Teachers understand students' needs & 0.735 & & & \\
\hline Teachers care about students' well-being & 0.766 & & & \\
\hline $\begin{array}{l}\text { Teachers are sincerely interested into } \\
\text { conveying knowledge to students }\end{array}$ & 0.748 & & & \\
\hline Teachers are approachable & 0.705 & & & \\
\hline Teachers have students' best interests in mind & 0.717 & & & \\
\hline Student trust & & 0.866 & 0.869 & 0.691 \\
\hline This faculty is a sincere institution & 0.776 & & & \\
\hline This faculty has high integrity & 0.837 & & & \\
\hline This faculty is a trustworthy institution & 0.877 & & & \\
\hline Student satisfaction & & 0.906 & 0.914 & 0.780 \\
\hline $\begin{array}{l}\text { My choice to enrol in this faculty was a wise } \\
\text { one }\end{array}$ & 0.931 & & & \\
\hline $\begin{array}{l}\text { I believe I did the right thing when I chose this } \\
\text { faculty }\end{array}$ & 0.933 & & & \\
\hline $\begin{array}{l}\text { I am satisfied with education I receive from this } \\
\text { faculty }\end{array}$ & 0.777 & & & \\
\hline $\begin{array}{l}\text { Relationship continuity } \\
\text { I would choose the same faculty if I were } \\
\text { starting higher education studies again }\end{array}$ & 0.902 & 0.773 & 0.788 & 0.654 \\
\hline $\begin{array}{l}\text { How likely is that you would choose the same } \\
\text { faculty if you were to enrol in higher level of } \\
\text { studies? }\end{array}$ & 0.704 & & & \\
\hline $\begin{array}{l}\text { Word-of-mouth } \\
\text { I would tell positive things about this faculty, if } \\
\text { asked for opinion }\end{array}$ & 0.880 & 0.850 & 0.854 & 0.745 \\
\hline $\begin{array}{l}\text { I would recommend this faculty to a friend or } \\
\text { relative who is interested into higher education }\end{array}$ & 0.846 & & & \\
\hline
\end{tabular}

${ }^{*}$ Note: Parameter estimates are significant at the 0.01 level 
Rajić T. et al.: An Integrative Model of Relationship Quality in Higher Education...

Source: authors' calculations

Reliability of the constructs was examined by calculating Cronbach's alpha coefficients and composite reliability (CR) of proposed constructs. Since all alpha values ranged between 0.773 and 0.906 , and were higher than the cutoff point of 0.60 , which is regarded acceptable in exploratory research (Hair et al., 2010) and all CRs were above 0.60 (Bagozzi \& Yi, 1988), evidence in support of the reliability of the constructs was provided. Statistically significant factor loadings of questionnaire items on their respective constructs, higher than the lower threshold of 0.50 (Anderson \& Gerbing, 1988) indicated convergent validity of the constructs. Convergent validity was also supported by average variance extracted of constructs (AVEs) which were higher than the lower bound of 0.50 (Fornell \& Larcker, 1981).

Discriminant validity of the constructs was assessed by examining confidence intervals $(\mathrm{Cl})$ of correlations among the constructs (Anderson \& Gerbing, 1988), which were obtained by the application of bootstrapping procedure with 1000 bootstrap samples. As none of the $95 \%$ confidence intervals contained one, as shown in Table 2, discriminant validity was acceptable. Content validity was also ensured as questionnaire items were taken from previous studies, where they were thoroughly tested.

Table 2. Correlations among constructs and confidence intervals of correlations *

\begin{tabular}{|c|c|c|c|c|c|}
\hline $\begin{array}{l}\text { Teachers' } \\
\text { customer } \\
\text { orientation }\end{array}$ & $\begin{array}{c}\text { Teachers' } \\
\text { customer } \\
\text { orientation } \\
1\end{array}$ & Trust & Satisfaction & $\begin{array}{l}\text { Relationship } \\
\text { continuity }\end{array}$ & $\begin{array}{l}\text { Word- } \\
\text { of- } \\
\text { mouth }\end{array}$ \\
\hline Trust & $\begin{array}{c}0.602 \\
(0.487-0.710)\end{array}$ & 1 & & & \\
\hline Satisfaction & $\begin{array}{c}0.492 \\
(0.365-0.611)\end{array}$ & $\begin{array}{c}0.610 \\
(0.477-0.711)\end{array}$ & 1 & & \\
\hline $\begin{array}{l}\text { Relationship } \\
\text { continuity }\end{array}$ & $\begin{array}{c}0.508 \\
(0.372-0.637)\end{array}$ & $\begin{array}{c}0.462 \\
(0.307-0.596)\end{array}$ & $\begin{array}{c}0.855 \\
(0.745-0.935)\end{array}$ & 1 & \\
\hline $\begin{array}{l}\text { Word-of- } \\
\text { mouth }\end{array}$ & $\begin{array}{c}0.534 \\
(0.416-0.647)\end{array}$ & $\begin{array}{c}0.685 \\
(0.575-0.781)\end{array}$ & $\begin{array}{c}0.843 \\
(0754-0.914)\end{array}$ & $\begin{array}{c}0.826 \\
(0.688-0.923)\end{array}$ & 1 \\
\hline
\end{tabular}

${ }^{*}$ Note: correlations are significant at the 0.05 level; Confidence intervals are presented in brackets

Source: authors' calculations

Relationships among the constructs were examined by the application of structural equation modelling (SEM), using maximum likelihood (ML) as a method of parameter estimation. Results of structural analysis indicate that 
Rajić T. et al.: An Integrative Model of Relationship Quality in Higher Education...

structural model fit was within an acceptable level $(X 2 / d f=2.273, \mathrm{GFI}=0.884$, $\mathrm{AGFI}=0.845, \mathrm{CFI}=0.942, \mathrm{NFI}=0.902, \mathrm{NNFI}=0.930, \mathrm{RMSEA}=0.074)$. Given the satisfactory fit of the structural model, path coefficients were further examined to test the hypotheses. Results of hypothesis testing are presented in Table 3.

Table 3. Structural model results

\begin{tabular}{|l|l|l|l|}
\hline \hline Relationships & $\begin{array}{l}\text { Standardized } \\
\text { parameter } \\
\text { estimates }\end{array}$ & T-value & $\begin{array}{l}\text { Hypothesis } \\
\text { testing }\end{array}$ \\
\hline H1: Student trust $\rightarrow$ Student satisfaction & 0.479 & 5.65 & supported \\
\hline $\begin{array}{l}\text { H2: Teachers' customer orientation } \rightarrow \\
\text { Trust }\end{array}$ & 0.601 & 7.55 & supported \\
\hline $\begin{array}{l}\text { H3: Teachers' customer orientation } \rightarrow \\
\text { Satisfaction }\end{array}$ & 0.228 & 2.92 & supported \\
\hline $\begin{array}{l}\text { H4: Student trust } \rightarrow \text { Relationship continuity } \\
\text { H5: Student trust } \rightarrow \text { Word-of-mouth }\end{array}$ & -0.096 & -1.46 & $\begin{array}{l}\text { Not } \\
\text { supported }\end{array}$ \\
\hline $\begin{array}{l}\text { H6: Student satisfaction } \rightarrow \text { Relationship } \\
\text { continuity }\end{array}$ & 0.936 & 3.91 & supported \\
\hline H7: Student satisfaction $\rightarrow$ Word-of-mouth & 0.714 & 10.01 & supported \\
\hline \hline
\end{tabular}

Source: authors' calculations

Results of the study indicate significant direct impact of student trust on satisfaction $(\beta=0.479, p<0.05)$, thus supporting hypothesis H1. Teachers' customer orientation emerged as a significant direct determinant of both trust and satisfaction, whereas teachers' behaviour towards students was of higher importance for the development of student trust $(y=0.601, p<0.05$ vs. $\gamma=0.228$, $\mathrm{p}<0.05$ ). Results of the study thus provided support to hypotheses $\mathrm{H} 2$ and $\mathrm{H} 3$. Contrary to initial expectations, trust was not found to be a significant direct determinant of relationship continuity $(\beta=-0.096, p>0.05)$ and support was not provided for hypothesis $\mathrm{H} 4$. However, trust emerged as a significant direct antecedent to students' willingness to spread positive word-of-mouth about the faculty $(\beta=0.244, p<0.05)$. These findings supported hypothesis H5. The direct impact of student satisfaction on both relationship continuity and wordof-mouth was significant $(\beta=0.936, p<0.05 ; \beta=0.714, p<0.05)$ Thus, these results supported hypotheses $\mathrm{H} 6$ and $\mathrm{H} 7$.

\section{Discussion}

Findings of this study point to the importance of students' perceptions of quality of a relationship with higher education institution, as favourable perceptions determine students' behavioural intentions, i.e. their willingness to enrol in the same faculty at a higher level of education and readiness to 
Rajić T. et al.: An Integrative Model of Relationship Quality in Higher Education...

spread positive WOM about the faculty. Students' perceptions of a quality relationship with the faculty are shaped by the behaviour of teachers, who are the most important frontline personnel of higher education institutions. Results of this study to a great extent resemble those of Cheng et al.'s (2008) and Huang et al.'s (2014) research who found that frontline personnel, their behaviour and attitude towards customers significantly add to customers' perceptions of the quality of a relationship with service provider.

This study's findings are consistent with the view of Casidy (2014) who found that students' positive perceptions of a university's market orientation alone do not contribute to student loyalty to the university. Rather, the development of student trust and satisfaction with the institution are important for students' willingness to continue a relationship with the faculty and spread positive WOM. Findings of this study are partially consistent with results of Ismanova (2019) who, on a sample of students attending higher education on Cyprus, reported insignificant direct relatedness of trust to student loyalty. However, by no means does this finding indicate insignificance of trust on students' future behaviour. Trust emerged as an indirect determinant of relationship continuity, whose impact is mediated via student satisfaction. Results of this study are also in compliance with the findings of Meštrović (2016) whose study on a sample of Croatian students resulted in significant direct impact of satisfaction on students' intentions to spread positive WOM about the faculty.

In order to improve customer orientation, higher education institutions should focus on understanding and fulfilling students' needs and responding to students' enquiries promptly. As student satisfaction eventually leads to relationship continuity and students' willingness to spread positive WOM, it is of utmost importance for higher education institutions to promote student satisfaction, by the adoption of student-oriented behaviour of its most important frontline personnel and instilling trust into students.. A possible approach to achieving this objective is to invest in internal marketing and create satisfied employees, as meeting the needs and wants of employees has been proved to contribute to customer satisfaction (Kim \& Cha, 2002).

Some limitations of the study should be acknowledged. First, the main limitations of the study are size and scope of the sample. The study was performed on a convenience sample of students attending one public higher education institution. Therefore, its findings cannot be generalized to higher education setting in Serbia as a whole. In order to circumvent this limitation, future research should be performed on a more randomized sample of students attending higher education in Serbia. Second, this study took into account only teachers' customer orientation as a determinant of students' perceptions of the quality of a relationship with higher education institution. Therefore, an examination of a more comprehensive model which would consider other possible determinants of relationship quality, such as e.g. 
Rajić T. et al.: An Integrative Model of Relationship Quality in Higher Education...

university image, which in a Spanish higher education setting emerged as a significant direct determinant of both trust and satisfaction (Schlesinger et al., 2017) would be in order. Future research might take into account contextspecific determinants of relationship quality. Third, this study examined the impact of teachers' customer orientation on students' perceptions of relationship quality. As students also establish direct communications with administrative staff of higher education institutions, the impact of their customer orientation on students' perceptions of relationship quality and future intentions should be also examined. Fourth, as attending higher education studies implies that students also experience institutional physical environment and are impacted by the policy of the institution, managerially relevant information might be provided by investigating the impact of interaction between students and institutional environment on students' perceptions of relationship quality. Fifth, although the survey was anonymous, we believe that data collection which has been performed during classes might have biased students' responses. Sixth, as this study employed a cross-sectional study design, this allows only correlational inferences to be made. Therefore, future studies should apply longitudinal study design in order to illuminate causal relationships among the constructs. On a continuum from tangible-dominant to intangible-dominant services, higher education is closer to the latter pole of the continuum. To enable better understanding of the relative impact of relationship quality dimensions on relationship continuity and customers' willingness to promote service provider, future studies may be extended to include customers of other types of services. The application of multi-group analyses to draw inferences regarding the antecedents and effects of relationship quality among various types of services would be in order.

\section{Conclusion}

Significant research attention has been devoted to the construct of relationship quality. However, few studies have empirically examined a framework of relationship quality in higher education setting. Aiming to bridge this research gap and add to the growing body of knowledge in relationship quality, the present study proposed and empirically examined the impact of teachers' customer orientation on students' perceptions of relationship quality and the effect of relationship quality on relationship continuity and WOM. This study's findings contribute to a better understanding of the relevance of adopting customer orientation in higher education setting.

In spite of a few limitations of the study, authors of this study contend that this study's findings bear relevant managerial information for higher education institutions' administrators. Results of this study point to the importance of 
Rajić T. et al.: An Integrative Model of Relationship Quality in Higher Education...

teachers' adoption of customer-oriented attitude and behaviour towards students, as such attitude and behaviour positively affect students' perceptions of a quality of a relationship with higher education institution, which further lead to relationship continuity and students' willingness to promote higher education institution. Due to specific nature of educational services, i.e. the fact that they exhibit all unique characteristics of services, such as intangibility, inseparability of production and consumption, variability, perishability, it is crucial for faculties' administrators to reduce risk and complexity which are inherent to these services, in order to ensure institutions' continuity. If higher education institutions can establish quality relationships with students, informational asymmetry at the side of students will be reduced and beneficial effects of high quality relationships can be expected.

\section{References}

Anderson, J. C., \& Gerbing, D. W. (1988). Structural equation modeling in practice: A review and recommended two-step approach. Psychological Bulletin, 103, 411423.

Annamdevula, S., \& Bellamkonda, R. S. (2016) The effects of service quality on student loyalty: the mediating role of student satisfaction. Journal of Modelling in Management, 11(2), 446-462.

Bagozzi, R. P., \& Yi, Y. (1988). On the evaluation of structural equation models. Journal of the Academy of Marketing Science, 16, 74-94.

Bejou, D., Wray, B., \& Ingram. T. N. (1996). Determinants of relationship quality: an artificial neural network analysis. Journal of Business Research, 36(2), 137-143.

Casidy, R. (2014). The role of perceived market orientation in the higher education sector. Australasian Marketing Journal, 22, 155-163.

Cheng, J.-H., Chen, F.-Y., \& Chang, Y.-H. (2008). Airline relationship quality: An examination of Taiwanese passengers. Tourism Management, 29, 487-499.

Chiou, J.-S. (2004). The antecedents of consumers' loyalty toward Internet Service Providers. Information \& Management, 41, 685-695.

Dado, J., Taborecka-Petrovicova, J., Riznic, D., \& Rajic, T. (2013). Linking service quality and satisfaction to behavioural intentions in higher education setting. Ekonomicky casopis, 61(6), 578-596.

Douglas, J. A., Douglas, A., McClelland, R. J., \& Davies, J. (2015). Understanding student satisfaction and dissatisfaction: an interpretive study in the UK higher education context. Studies in Higher Education, 40(2), 329-349.

Fornell, C., \& Larcker, D. F. (1981). Evaluating structural equation models with unobservable variables and measurement error. Journal of Marketing Research, 18, 39-50.

Ghosh, A. K., Whipple, T. W., \& Bryan, G. A. (2001). Student Trust and its Antecedents in Higher Education, The Journal of Higher Education, 72(3), 322340.

Guilbault, M.(2016). Students as customers in higher education: reframing the debate. Journal of Marketing for Higher Education, 26(2), 132-142. 
Rajić T. et al.: An Integrative Model of Relationship Quality in Higher Education...

Guilbault, M. (2018). Students as customers in higher education: The (controversial) debate needs to end. Journal of Retailing and Consumer Services, 40, 295-298.

Hair, J.F., Anderson, R.E., Tatham, R.L. \& Black, W. C. (2010). Multivariate Data Analysis: A Global Perspective (7th ed). New Jersey: Pearson Prentice Hall.

Harris, L. C., \& Goode, M. M.H. (2004). The four levels of loyalty and the pivotal role of trust: a study of online service dynamics. Journal of Retailing, 80, 139-158.

Helgesen, Ø., \& Nesset, E.(2007). What accounts for students' loyalty? Some field study evidence. International Journal of Educational Management, 21(2), 126143.

Hemsley-Brown, J., \& Oplatka, I. (2010). Market orientation in universities: A comparative study of two national higher education systems. International Journal of Educational Management, 24(3), 204-220.

Hsieh, Y.-C., \& Hiang, S.-T. (2004). A Study of the Impacts of Service Quality on Relationship Quality in Search-Experience-Credence Services. Total Quality Management, 15(1), 43-58.

Huang, J.-A., Lai, C.-S., Hu, J.-S., \& Weng, R.-H. (2014). The impact of market orientation on patient loyalty: the mediation of relationship quality. Service Business, 8(4), 499-515.

Ismanova, D. (2019). Students' loyalty in higher education: The mediating effect of satisfaction, trust, commitment on student loyalty to Alma Mater. Management Science Letters, 9, 1161-1168.

Izogo, E. E. (2016). Structural equation test of relationship quality. International Journal of Emerging Markets, 11(3), 374-394.

Kim, W. G., \& Cha, Y. (2002). Antecedents and consequences of relationship quality in hotel industry. International Journal of Hospitality Management, 21, 321-338.

Kim, W. G., Lee, Y.-K, \& Yoo, Y.-J. (2006). Predictors of Relationship Quality and Relationship Outcomes in Luxury Restaurants. Journal of Hospitality \& Tourism Research, 30, 143-169.

Kirca, A. H., Jayachandran, S., \& Bearden, W. O. (2005). Market Orientation: A MetaAnalytic Review and Assessment of Its Antecedents and Impact on Performance. Journal of Marketing, 69(2), 24-41.

Meštrović, D., (2016, September). The Impact of Service Quality on Students' Satisfaction and the Word-of-Mouth: The Case of the University of Rijeka Departments. Paper presented at the International Multi-disciplinary Conference ENTerprise REsearch InNOVAtion (ENTRENOVA '16), Croatia, Rovinj, 2, 4-10.

Meštrović, D. (2017). Service quality, students' satisfaction and behavioural intentions in STEM and IC higher education institutions. Interdisciplinary Description of Complex Systems, 15(1), 66-77.

Narver, J. C., \& Slater, S. F. (1990). The Effect of a Market Orientation on Business Profitability. Journal of Marketing, 54(4), 20-35.

Oliver, R. L. (1997). Satisfaction, A Behavioral perspective on the Consumer, USA, Boston: Irwin/McGraw-Hill

Qin, S., Zhao, L., \& Yi, X. (2009). Impacts of customer service on relationship quality: an empirical study in China. Managing Service Quality, 19(4), 391-409.

Rajaobelina, L., \& Bergeron, J. (2009). Antecedents and consequences of buyer-seller relationship quality in the financial services industry. International Journal of Bank Marketing, 27(5), 359-380. 
Rajić T. et al.: An Integrative Model of Relationship Quality in Higher Education...

Rojas-Méndez, J., Vásquez, P. A., Kara, A., \& Cerda-Urrutia, A. (2009). Determinants of Student Loyalty in Higher Education: A Tested Relationship Approach in Latin America. Latin American Business Review, 10, 21-39.

Saxe, R., \& Weitz, B. A. (1982). The SOCO Scale: A Measure of the Customer Orientation of Salespeople. Journal of Marketing Research, 19(3), 343-351.

Schlesinger, W., Cervera, A., Pérez-Cabañero, C. (2017). Sticking with your university: the importance of satisfaction, trust, image, and shared values. Studies in Higher Education, 42(12), 2178-2194.

Sharma, S. K., \& Sharma, M. (2019). Examining the role of trust and quality dimensions in the actual usage of mobile banking services: An empirical investigation, International Journal of Information Management, 44, 65-75.

Statistical office of the Republic of Serbia. (1999-2018). Municipalities and regions of the Republic of Serbia. Retrieved from: http://www.stat.gov.rs/enUS/publikacije/?d=13\&r=

Šályová, S., Táborecká-Petrovičová, J., Nedelová, G., \& Ďad’o, J. (2015). Effect of Marketing Orientation on Business Performance: A Study from Slovak Foodstuff Industry, Paper presented at the Business Economics and Management 2015 Conference, BEM2015, Procedia Economics and Finance, 34, 622 - 629.

Šályová, S., Táborecká-Petrovičová, J., \& Kaščáková, A. (2017, March). Market orientation of companies with the brand "Značka kvality SK", Paper presented at the CBU International conference on innovations in science and education, Czech Republic.

Taylor, S. Jr., DiPietro, R. B., \& Fung, S. K. K. (2018). Increasing experiential value and relationship quality: An investigation of pop-up dining experiences. International Journal of Hospitality Management, 74, 45-56.

Voon. B.H. (2008). SERVMO: A Measure for Service-Driven Market Orientation in Higher Education. Journal of Marketing for Higher Education, 17(2), 216-237.

Wu, H.-C., Cheng, C.-C., \& Hussein, A.S. (2019). What drives experiential loyalty towards the banks? The case of Islamic banks in Indonesia. International Journal of Bank Marketing, 37(2), 595-620. 